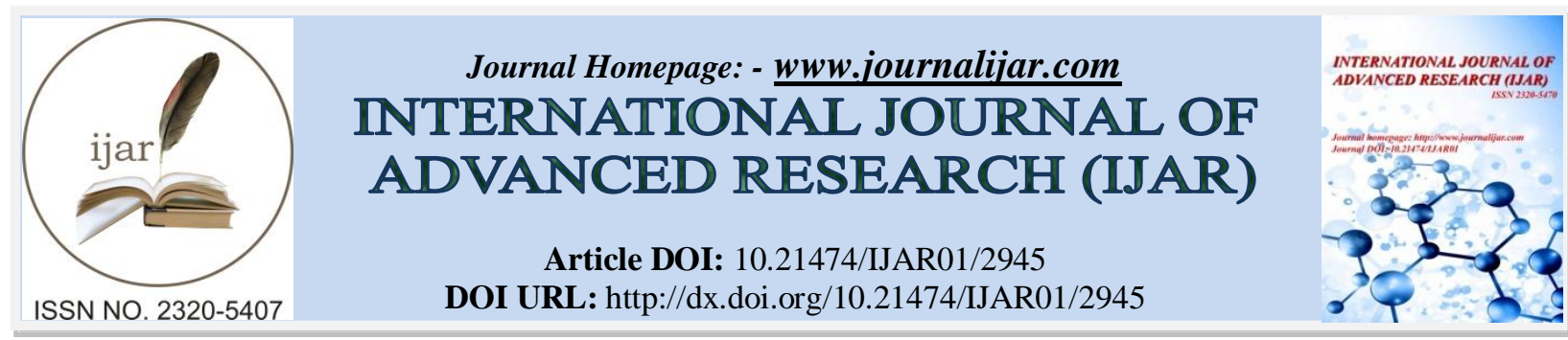

RESEARCH ARTICLE

\title{
A STUDY ON SOCIO-ECONOMIC AND CULTURAL PROFILE OF FISHERMEN IN PUDUCHERRY REGION, INDIA.
}

\section{Dr. R. Karuppusamy ${ }^{1}$ and K. Karthikeyan ${ }^{2}$.}

1. Principal Investigator, UGC Major Research Project, Associate Professor of Commerce \& Research supervisor, PG and Research Department of Commerce, Kanchi Mamunivar Centre for PG Studies, Puducherry - 605008.

2. Project Fellow, UGC Major Research Project \& Ph.D. Research Scholar in Commerce, PG and Research Department of Commerce, Kanchi Mamunivar Centre for PG Studies, Puducherry - 605008.

\section{Manuscript Info}

(..........................

Manuscript History

Received: 25 November 2016

Final Accepted: 27 December 2016

Published: January 2017

Key words:-

Fishermen, socio-economic condition,

Fishing.

\section{Abstract}

The study focused on the socio-economic and cultural profile of the fishermen living in community villages in Puducherry Region. The objective of the study is to analyse the socio-economic conditions as well as the problems faced by the fisher folk. To study the factors 200 sample respondents were interviewed with duly constructed schedule of questions by using the simple random sampling method. The outcome of the study revealed that $92 \%$ belong to Hindus and very meager (8\%) from Christian community. Fishermen venture into sea is aging between 41 and 45 years (43\%) and they only have primary level education. Regarding their income it ranges between Rs. 5,000 and Rs.20,000 p.m. Only $12 \%$ of the respondents earn more than Rs.20,000 p.m. Majority of the respondents are living in the Government provided tsunami houses. Rest of them dwells in their own house. Good majority of the fishermen habituated to use latest mobile phones (86\%) and accustomed to live with basic necessities such as TVs and other home appliances despite of their low income. Puducherry is famous for liquor since its French regime. Therefore most of the fishermen (62\%) addict to liquor. More than 30\% of their total income is spent for consumption of liquor. This is the cause of concern for this community. The major problems of fishermen were identified as selling of fish, price fixing, marketplace \& finance for investment. Those problems are perceived by the fishermen as serious issues. The fishermen expect the from the Government to arrange certain facilities like short period loans, transportation, set up of more fish markets and processing units open for marketing of fish.

Copy Right, IJAR, 2016,. All rights reserved.

\section{Introduction:-}

Fishing is the ancient and one of the most important livelihood options of the inhabitants of the coastal line of the country since the time immemorial. Fish and fisheries is an important sector in most of the developing and developed countries of the world from the standpoint of income and employment generation. It is one of the oldest economic activities of the human race and ranks next to agriculture. The fisher folk purely depend on the marine

Corresponding Author:- Dr.R.Karuppusamy.

Address:- Principal Investigator, UGC Major Research Project, Associate Professor of Commerce \& Research supervisor, PG and Research Department of Commerce, Kanchi Mamunivar Centre for PG Studies, Puducherry - 605008 . 
environment for their day-to-day affairs and it has been considered as the custodian of livelihood security. The fisheries sector contributes to the national income, exports, food and nutritional protection and employment generation. Approximately, $1 \%$ of the total populations rely on the fishery sector in India as a primary source of income and life dependency. (Ministry of Statistics and Programme Implementation, 2011). India occupies the third position in fish production and second in aquaculture production in the world ranking. The fish production in the country in 2014-15 was 100.69 lakh tones, of which 34.91 lakh tones were harvested from marine sector and the rest was from inland sector. The rapid economic growth and expansion of the domestic retail sector in India has created a significant market for fresh and processed fish and fishery products within the country (Sathiadhas, et al. 2011).Indian fishery sector significantly contribute to foreign exchange too.

\section{Puducherry and Fishery:-}

The Union Territory of Puducherry comprises of four regions, viz., Puducherry, Karaikal, Mahe \& Yanam. The UT's capital is the city of Puducherry. The UT of Puducherry has total fishermen population around 95,467 (Dept. of Fisheries statistics, Puducherry) of which 29,383 fishermen are actively engaged in fishing from 29 marine fishing villages and 23 inland fishing villages / hamlets scattered across the region. For this study, the researcher has taken three dense populated fishing villages. First, Veerampattinam village has 1,777 fishermen families, second Vambakeerapalayam has 1,390 fishermen families and the third one is Solainagar has 767 fishermen families.

\section{Review of Literature:-}

Basavakumar et al. (2011) the research paper entitled "A study on profile of fishing community of a village in Karnataka" from Dharwad district. The study revealed that the male population constitute around 52.33 per cent and 13.84 per cent of fishermen are only literate. It is noted that 56.14 per cent respondent's income was less than of 30,000 per month. The study also reveals that smoking, betel nut chewing and consumption of liquor were the common habits of adult fishermen.

Bijayalakshmi and Ajitkumar (2014) in their research paper "Socio-economic conditions and cultural profile of the fishers in India- a review" states that the socio-economic conditions of the fisheries in India are considerably low. Fishers generally have pursued less education and live under improper housing conditions. With a very low income from fishing, fishers supported large members in the family which compels the fishermens to borrow credits to fulfill their basic needs. The study concluded that proper fishery management policies, effective input supply, technical and social supports may improve the livelihood of the fishers which will ultimately increase the overall fisheries productivity of India.

Tapashi and Methra (2014) in their paper "Socio-economic and cultural profile of fish farmers: A study in and around Lumding town, Nagaon District of Assam" the data were collected from 110 respondents by using random sampling method. It was found that most of the inland fish farmers belong to the scheduled caste and majority of the fish farmers had their own land and practiced fish farming as a primary occupation for many decades. Their income from fish farming was too low (between Rs. 20,000 and 30,000/- p.a.). Most of them took financial help from their friends and relative of their day to day investment. They spent their major earnings for basic needs, food and children's education. Poverty, lack of marketing facilities and lack of technical training are the major hurdles they face.

Kadam (2015) in his paper entitled "Socio economic conditions of fishermen of Masoli Reservoir, in Gangakhed (Tq), Parbhani Dist., Maharashtra state, India" the data collected from 35 families. The results disclosed that 45.26\% of the fishers are literate and the economic status of the people was fairly poor as they are unable to engage work due to many reasons. They used traditional fishing methods instead of modern aquaculture techniques. The Govt. of Maharashtra provides fishermen welfare programmes such as Group Accident Insurance Scheme for active fishermen, Development of Model Fishermen Villages etc.

Jacob and Rao (2015) in their article "Socio-ecological studies on marine fishing villages in the selective south coastal districts of Andhra Pradesh", the study revealed that the fishermen in coastal villages are in pathetic condition because of poverty and lack of financial support either from the Govt. or from the banks. The study reveals that almost, $90 \%$ of the traditional fishermen live below poverty line. The large scale industrialization in the recent years in coastal areas without having any strict regulatory framework has a devastating impact on the marine livestock, health of fishermen and their livelihood. The fishing villages are totally deprived of the basic infrastructure such as proper drinking water, connectivity of road, street electrification and good sanitation. 


\section{Statement of the Problem:-}

Pondicherry lies on the east coast of Bay of Bengal therefore; emergence of fishing and related activities is inevitable among the people of coastal villages naturally called as fishermen. Their productive capacity, performance and earnings are based on their living style, comforts, societal investments and economic status. Despite the enormous increase in the fishermen population, their prosperity, welfare and development is measured by the Government are seemed to be not up to the mark. Hence, this is to be addressed. Majority of the fishermen family live in below poverty line. Their financial instability, low profile in socio-economic status brought them down to earth not allowing them to prosper in their life. The fishermen's children aspire for good education but they are unable to pursue because of the inability of family head to spare considerable money for that purpose. All these factors rely on the prosperity of the fishermen community who dwell in the areas in which basic facilities like pure drinking water, sanitation and toilets are still inadequate. Taking in to account of the facts, it would be pertinent to study the socio-economic factors and problems of fishermen community in Pondicherry Region.

\section{Objectives of the Study:-}

The following are the basic objectives of the study.

1. To study the Socio-Economic status and problem faced by the fishermen in Puducherry Region.

2. To suggest better ways and means for improving the standard of living of the fishermen.

\section{Methodology:-}

The data required for the study have been obtained from both primary and secondary sources. The primary data were collected through interview schedule and secondary sources of data were collected through books, journals, magazines and related websites. Three fishermen outfits had been chosen for this study Viz., Veerampattinam, Vambakeerapalayam and Solainagar in Puducherry region. The combined populations of three villages are15,736. Out of which 70 respondents from each villages has been chosen on the basis of simple random sampling method. Out of 210 samples ten respondents neither provide necessary information nor co-operate to the investigator. Hence, 200 samples were finally taken for the study.

\section{Socio-Economic Research Variables:-}

In the fisheries, socio-economic status of fishermen plays a key role in their productive activities. Socio-economic parameters such as religion of fishermen, castes, age, marital status, standard of living, duration of stay, family structure, member of family, earning members in family, employment of sons /daughters, member of family venture into sea, occupation of female households, residence ownership, nature of house, toilet facilities, food habit, source of lighting, household amenities, cultural activities, competition among inland fishermen, consumption habits of fishermen are considered as important variables for analysis.

\section{Analysis and Interpretation:-}

The Socio-economic profile of the Fishermen in the study area was analysed and the results are presented in table 1.

Table 1:- Socio-Economic Profile of Fishermen

\begin{tabular}{|c|c|c|c|c|}
\hline No. & \multicolumn{2}{|c|}{ SOCIOECONOMIC PROFILE } & Frequency & Percentage \\
\hline \multirow{4}{*}{1.} & \multirow{4}{*}{$\begin{array}{l}\text { Religion of } \\
\text { Fishermen }\end{array}$} & Hindu & 184 & $92 \%$ \\
\hline & & Christian & 16 & $8 \%$ \\
\hline & & Muslim & 0 & $0 \%$ \\
\hline & & Total & 200 & $100 \%$ \\
\hline \multirow[t]{6}{*}{2.} & \multirow[t]{6}{*}{ Castes of Fishermen } & Scheduled Caste & 0 & $0 \%$ \\
\hline & & Scheduled tribe & 0 & $0 \%$ \\
\hline & & E.B.C & 200 & $100 \%$ \\
\hline & & M.B.C & 0 & $0 \%$ \\
\hline & & General & 0 & $0 \%$ \\
\hline & & Total & 200 & $100 \%$ \\
\hline \multirow[t]{6}{*}{3.} & \multirow[t]{6}{*}{ Age of Fishermen } & Below 30 years & 22 & $11 \%$ \\
\hline & & $31-35$ years & 16 & $8 \%$ \\
\hline & & $36-40$ years & 28 & $14 \%$ \\
\hline & & $41-45$ years & 86 & $43 \%$ \\
\hline & & Above 45 years & 48 & $24 \%$ \\
\hline & & Total & 200 & $100 \%$ \\
\hline
\end{tabular}




\begin{tabular}{|c|c|c|c|c|}
\hline \multirow[t]{4}{*}{4.} & \multirow{4}{*}{ Marital Status of Fishermen } & Married & 176 & $88 \%$ \\
\hline & & Unmarried & 24 & $12 \%$ \\
\hline & & Others & 0 & $0 \%$ \\
\hline & & Total & 200 & $100 \%$ \\
\hline \multirow[t]{6}{*}{5.} & \multirow{6}{*}{$\begin{array}{l}\text { Educational } \\
\text { Status of Fishermen }\end{array}$} & Uneducated & 32 & $16 \%$ \\
\hline & & Up to Primary & 130 & $65 \%$ \\
\hline & & Secondary & 28 & $14 \%$ \\
\hline & & Higher Secondary & 4 & $2 \%$ \\
\hline & & Degree and above & 6 & $3 \%$ \\
\hline & & Total & 200 & $100 \%$ \\
\hline \multirow[t]{3}{*}{6.} & \multirow{3}{*}{ Standard of living } & Above poverty line & 10 & $5 \%$ \\
\hline & & Below poverty line & 190 & $95 \%$ \\
\hline & & Total & 200 & $100 \%$ \\
\hline \multirow[t]{6}{*}{7.} & \multirow{6}{*}{ Duration of stay } & $1-5$ years & 8 & $4 \%$ \\
\hline & & $6-15$ years & 2 & $1 \%$ \\
\hline & & $16-25$ years & 36 & $18 \%$ \\
\hline & & $26-35$ years & 16 & $8 \%$ \\
\hline & & Above 35 years & 138 & $69 \%$ \\
\hline & & Total & 200 & $100 \%$ \\
\hline \multirow[t]{3}{*}{8.} & \multirow[t]{3}{*}{ Family Structure } & Nuclear family & 130 & $65 \%$ \\
\hline & & Joint family & 70 & $35 \%$ \\
\hline & & Total & 200 & $\mathbf{1 0 0}$ \\
\hline \multirow[t]{4}{*}{9.} & \multirow[t]{4}{*}{ Number of members in the family } & Up to 3 members & 18 & $9 \%$ \\
\hline & & 4 to 5 members & 118 & $59 \%$ \\
\hline & & Above 5 members & 64 & $32 \%$ \\
\hline & & Total & 200 & $100 \%$ \\
\hline \multirow[t]{4}{*}{10.} & \multirow{4}{*}{$\begin{array}{l}\text { Number of earning members in } \\
\text { the family }\end{array}$} & Up to 3 members & 164 & $82 \%$ \\
\hline & & 4 to 5 members & 20 & $10 \%$ \\
\hline & & Above 5 members & 16 & $8 \%$ \\
\hline & & Total & 200 & $100 \%$ \\
\hline \multirow[t]{5}{*}{11.} & \multirow{5}{*}{$\begin{array}{lll}\text { Employment of } & \text { their Sons } \\
\text { Daughters(200-24 } & \text { (Unmarried) }= \\
176) & \end{array}$} & Fish catch & 126 & $71.59 \%$ \\
\hline & & Private Job & 36 & $20.46 \%$ \\
\hline & & Govt. Job & 4 & $2.27 \%$ \\
\hline & & Students & 10 & $5.68 \%$ \\
\hline & & Total & 176 & $100 \%$ \\
\hline \multirow[t]{3}{*}{12.} & \multirow{3}{*}{$\begin{array}{l}\text { Occupation of Fisherwomen } \\
(200-24(\text { Unmarried })=176)\end{array}$} & Housewife & 70 & $39.8 \%$ \\
\hline & & Fish Vendors & 106 & $60.2 \%$ \\
\hline & & Total & 176 & $100 \%$ \\
\hline \multirow[t]{4}{*}{13.} & \multirow{4}{*}{$\begin{array}{l}\text { Ownership residence of the } \\
\text { respondents }\end{array}$} & Rented House & 4 & $2 \%$ \\
\hline & & Own House & 70 & $35 \%$ \\
\hline & & $\begin{array}{l}\text { Govt. Provided Tsunami } \\
\text { House }\end{array}$ & 126 & $63 \%$ \\
\hline & & Total & 200 & $100 \%$ \\
\hline \multirow[t]{4}{*}{14.} & Nature of House & Thatched House & 4 & $2 \%$ \\
\hline & & Titled House & 34 & $17 \%$ \\
\hline & & Concrete House & 162 & $81 \%$ \\
\hline & & Total & 200 & $100 \%$ \\
\hline 15. & Usage Telephone/Mobile & Landline Telephone & 4 & $2 \%$ \\
\hline & & Mobile Phone & 172 & $86 \%$ \\
\hline & & Having Both & 2 & $1 \%$ \\
\hline & & Not Having Both & 22 & $11 \%$ \\
\hline & & Total & 200 & $100 \%$ \\
\hline
\end{tabular}




\begin{tabular}{|c|c|c|c|c|}
\hline \multirow[t]{4}{*}{16.} & \multirow[t]{4}{*}{ Food Habit } & Rice with fish & 200 & $100 \%$ \\
\hline & & Wheat & 0 & $0 \%$ \\
\hline & & Others & 0 & $0 \%$ \\
\hline & & Total & 200 & $100 \%$ \\
\hline \multirow[t]{4}{*}{17.} & \multirow[t]{4}{*}{ Source of Lighting } & Electricity & 200 & $100 \%$ \\
\hline & & Kerosene & 0 & $0 \%$ \\
\hline & & Solar & 0 & $0 \%$ \\
\hline & & Total & 200 & $100 \%$ \\
\hline \multirow[t]{5}{*}{18.} & \multirow[t]{5}{*}{$\begin{array}{l}\text { Attitude towards entertainment of } \\
\text { fishermen }\end{array}$} & $\begin{array}{l}\text { Reading Newspapers \& } \\
\text { Magazines }\end{array}$ & 36 & $18 \%$ \\
\hline & & Listening Radio & 2 & $1 \%$ \\
\hline & & Watching T.V & 156 & $78 \%$ \\
\hline & & Cinema & 6 & $3 \%$ \\
\hline & & Total & 200 & 100 \\
\hline \multirow[t]{3}{*}{19.} & \multirow{3}{*}{$\begin{array}{l}\text { Conflicts / Competition among } \\
\text { inland fishermen }\end{array}$} & Yes & 8 & $4 \%$ \\
\hline & & No & 192 & $96 \%$ \\
\hline & & Total & 200 & $100 \%$ \\
\hline
\end{tabular}

Source: Primary data

Religion, Caste \& Age of respondents: Hindus were featured as the absolute majority ( 92 per cent) among the fishermen in those villages. Meager 8 per cent are Christians. No Muslim fishermen found in the study area. Most of the fishermen are belong to fishermen community which comes under "Extreme Backward Class" (EBC). Majority of the fishermen ( 43 per cent) are at the age group between 41 and 45 years, 25 per cent of respondents are above 45 years, 14 per cent of the respondents aged between 36 years and 40 years, 11 per cent respondents are aged below 30 years. Meagre ( 8 per cent) respondents are aged between 31 and 35 years.

Education, Marital Status and Standard of living: Education plays a vital role in efficient management and successful production of fish. An educated fisherman easily adopts new technology than an uneducated one. With regard to the education status of fishermen, 65 per cent of respondents have only primary level of education, 14 per cent of respondents at secondary level. Further, it was found that 16 per cent of the respondents are uneducated. Fishermen possess higher secondary education and above are only 5 per cent.

Marital status is the important factor for socio-economic and cultural profile of fisher folk because this factor molds behaviour of the any individual. It is evident from this study that 88 per cent of the respondents are found to be married and the remaining 12 per cent are unmarried. Taking into account of standard of living, the study divided into two categories viz., living below and above poverty line. The Government of Puducherry issued ration cards based on their income level. The red ration card holders are identified as living below the poverty line and yellow ration card holders are treated as living above the poverty line. The study reveals that 95 per cent fishermen (possess red cards) are living below poverty line and the rest (5 per cent yellow card holders) are in the above poverty line.

Duration of stay: Regarding duration of stay, most of the fishermen (69 per cent) live in the same locality for more than 35 years. The study also revealed that 31 per cent of the respondents migrated from other locality (villages) within Puducherry region for getting better employment, children's education, transportation etc.

Family Structure: Family structure is another important factor for analyzing socio-economic status of fishermen. In the present of study, families were classified into two types such as nuclear family and joint family. Majority (65 per cent) of fishermen are living as nuclear family and 35 per cent as joint family. The size of the family has considerable influence on the income and expenditure pattern of the family.

Number of members in the family: Around 60 per cent of the fishermen family have 4 to 5 members followed by fishermen family have more than 5 members ( 32 per cent). Only 9 per cent have only 3 family members. 
Number of earning members in the family: It was revealed that, majority ( 82 per cent) of the respondents family three members work and earn income for their family. Only 8 per cent of the respondents, all the members of family go for work and earn for their livelihood.

Employment of their sons / daughters: God majority of the fishermen ( 71.59 per cent) sons \& daughter (unmarried) engage fishing and related activities. Only 20.46 per cent of the fishermen children go for private job. Very meagre 2.27 per cent fishermen sons and daughters could get the Government job and $5.68 \%$ of sons/daughters of fishermen are students.

Occupation of fisherwomen: The occupation of fisherwomen (60.2 per cent) is fish vending and 39.8 per cent of fisherwomen manage house.

Ownership of residence: The residential house of the fishermen (63 per cent) is Government provided Tsunami houses. 35 per cent of fishermen reside in their own house and only 2 per cent live in rented house.

Nature of house: Housing pattern is one of the most important indicators used to assess the economic well-being of any community. During the survey, attempts were made to find out the conditions of living house of the fishermen. The study revealed that good majority of fishermen are living in concrete house ( 81 per cent) followed by the titled house (17 per cent) and thatched house is 2 per cent. This reflects the better living condition of the people in the study area. The reason because the Govt. has provided tsunami house to fishermen.

Usage of telephone /mobile phone: Majority ( 86 per cent) of the fishermen use mobile phones where as only 2 per cent use landline telephone. Both mobile phone and landline telephone using respondents are only one per cent. It is interested to state that 11 per cent of the respondents neither use mobile nor use landline phone because they are unable to buy the costly gadgets. During emergency needs they use phone of their relatives or neighbours.

Food Habit: Regarding food pattern of the fishermen in Puducherry region, cent of fishermen take rice with fish gravy. Because they like the taste of food and most of them add fish in day-to-day food habit. No one prefers wheat related food in their homes.

Source of lighting: It was found that all the respondents in the study area are using the electricity as source of lighting. They use the Kerosene lamp or candle as alternative source of lighting if electricity fails.

Entertainment Actives: The entertainment activities of fishermen are watching T.V (78 per cent)followed by reading newspaper\& magazines (in vernacular) is 18 per cent then going to cinema theaters is 3 per cent and listening to FM radio is only one per cent.

Conflicts / Competition: The study reveals that 96 per cent of the fishermen expressed that there is no conflict/competition between the fishermen in respect of their employment or any other socio-cultural aspects.

Table 2:- Adequacy basic facilities to the Fishermen

\begin{tabular}{|l|l|l|l|l|}
\hline No. & Basic Facilities & Adequate & Inadequate & Total \\
\hline 1. & Access to safe drinking water & $69 \%$ & $31 \%$ & $100 \%$ \\
\hline 2. & Proper Sanitation facilities & $69 \%$ & $31 \%$ & $100 \%$ \\
\hline 3. & Access to healthcare facilities & $78 \%$ & $22 \%$ & $100 \%$ \\
\hline
\end{tabular}

Source: Primary data

From the above table it is found that the basic facilities like provision of clean\& safe drinking water, proper sanitation facilities and accessibility of healthcare facilities are considered as vital factors for the healthy society. The study reveals that $70 \%$ of the respondents agreed that the Government of Puducherry have provided a good sanitation facility, safe and clean drinking water facilities. Good majority of respondents opined that health care facilities are adequate. 
Table 3:- Toilet facilities available to the Fishermen

\begin{tabular}{|l|l|l|}
\hline Toilet Facilities & Frequency & Per cent \\
\hline Yes & 160 & $80 \%$ \\
\hline No & 40 & $20 \%$ \\
\hline Total & $\mathbf{2 0 0}$ & $\mathbf{1 0 0 \%}$ \\
\hline If No, Toilet facilities & Frequency & Per cent \\
\hline \multicolumn{2}{|l|}{} \\
\hline Open Place & 32 & $80 \%$ \\
\hline Govt. Provided common toilets & 8 & $20 \%$ \\
\hline Total & $\mathbf{4 0}$ & $\mathbf{1 0 0 \%}$ \\
\hline
\end{tabular}

Source: Primary data

Table -3 shows that the availability and usage of toilets are one of the important yardsticks of the socio-economic factors to measure their life style. Hence, the question was raised among the respondents to the find the availability and usage of toilets. It was found that 80 per cent of fishermen have own toilet facilities in their residence, but 20 per cent of fishermen have no toilet facilities and they go either open place or common toilets for their natural calls.

Table 4:- Monthly Income of Fishermen

\begin{tabular}{|c|l|l|l|}
\hline No. & Monthly Income & Frequency & Per cent \\
\hline 1. & Below Rs. 5000 & 0 & $0 \%$ \\
\hline 2. & Rs. 5000-10000 & 24 & $12 \%$ \\
\hline 3. & Rs. 10001-15000 & 106 & $53 \%$ \\
\hline 4. & Rs.15001-20000 & 46 & $23 \%$ \\
\hline 5. & Above Rs. 20000 & 24 & $12 \%$ \\
\hline & Total & $\mathbf{2 0 0}$ & $\mathbf{1 0 0 \%}$ \\
\hline
\end{tabular}

Source: Primary data

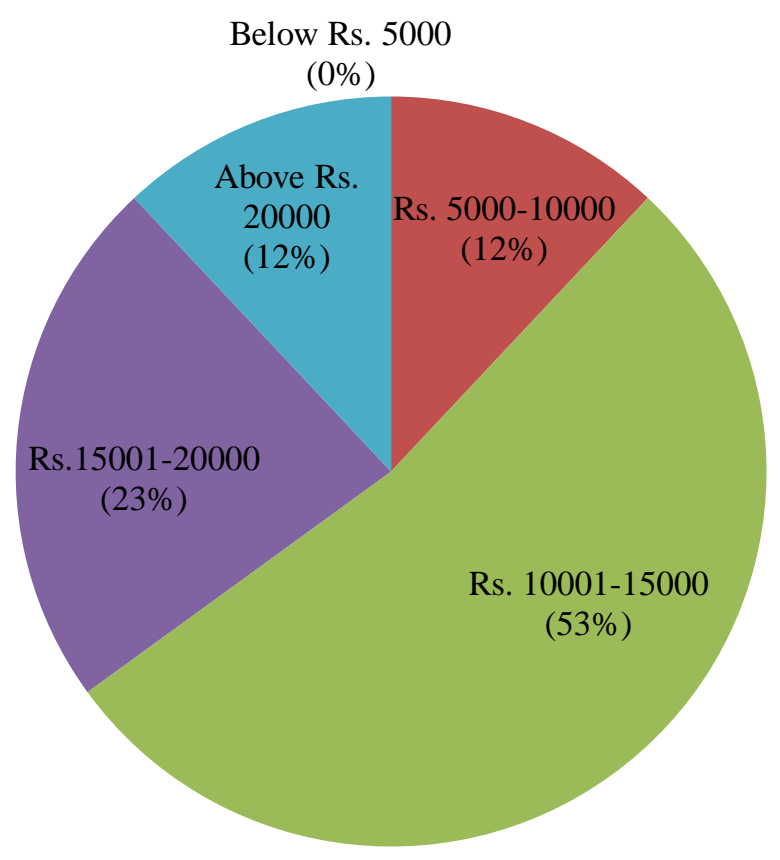

In general, employment and income are the twin decisive factors mostly used to determine the living standard of any community. Equitable distribution of income further enhances the social harmony among different sections of population. In this connection, the monthly income of the respondents was found that 53 per cent of respondents earn income between Rs. 10,000 and 15,000 p.m. followed by 23 per cent earn between Rs. 15,000 and Rs. 20,000 p.m. Only 12 per cent of the fishermen earn more than Rs. 20,000 p.m. 
Table 5:- Habits of the Fishermen

\begin{tabular}{|c|l|l|l|}
\hline No. & Habits of fishermen & Frequency & Per cent \\
\hline 1. & Beedi / Cigarettes / Pan & 2 & $1 \%$ \\
\hline 2. & Liquor & 124 & $62 \%$ \\
\hline 3. & All of these & 28 & $14 \%$ \\
\hline 4. & Clean habits & 46 & $23 \%$ \\
\hline & Total & $\mathbf{2 0 0}$ & $\mathbf{1 0 0 \%}$ \\
\hline
\end{tabular}

Source: Primary data

\section{Exhibit -2: Habits of Fishermen}

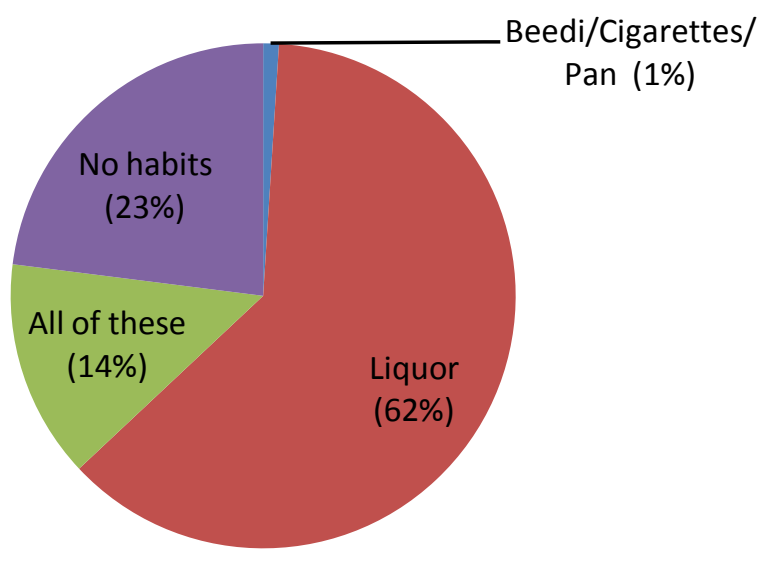

Table 5a:- Income spent on Alcohol consumption

\begin{tabular}{|c|l|l|l|}
\hline & Income spent on Alcohol consumption & Frequency & Per cent \\
\hline 1. & Spent less than 10\% & 12 & $8 \%$ \\
\hline 2. & Spent $10-20 \%$ & 16 & $10 \%$ \\
\hline 3. & Spent $20-30 \%$ & 106 & $69 \%$ \\
\hline 4. & Spent above $30 \%$ & 20 & $13 \%$ \\
\hline & Total & $\mathbf{1 5 4}$ & $\mathbf{1 0 0 \%}$ \\
\hline
\end{tabular}

Source: Primary data

Exhibit -3: Income spent on Alcohol Consumption

(On Monthly Income)

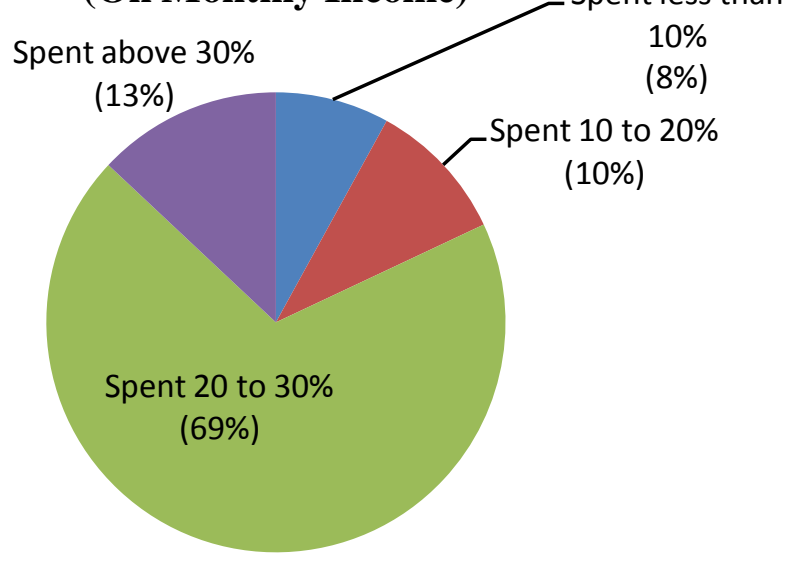


Table 5b:- Place of consumption of Alcohol

\begin{tabular}{|c|l|l|l|}
\hline & Place of Consumption of Alcohol & Frequency & Per cent \\
\hline 1. & Bar & 102 & $67 \%$ \\
\hline 2. & Home & 50 & $33 \%$ \\
\hline & Total & $\mathbf{1 5 2}$ & $\mathbf{1 0 0 \%}$ \\
\hline
\end{tabular}

Source: Primary data

It is evident that liquor consumption is quite common among the people of Puducherry, particularly among the fishermen community. Table-5reveals that majority 102 respondents of the respondents have the habit of consume liquor regularly. Out of which, 67 per cent of respondents go to local bars for liquor in-take, rest of them consume liquor in their home itself. Further, it is keen to observe that majority (69\%) of the respondents spend around 30 per cent of their total earnings for liquor consumption. It is noteworthy to state that 46 (23 per cent) respondents have clean habits.

Problems Faced by Fishermen:-

The study also analysed the basic problems faced by the fishermen community. The data were analysed and results are presented in the table 6.

Table 6:- Problems faced by the fishermen (NAP-Not at all Problem, MIP-Minor Problem, MOP-Moderate Problem, SP-Serious Problem)

\begin{tabular}{|l|l|l|l|l|l|l|l|l|}
\hline S.No & Problems faced by the fishermen & NAP & MIP & MOP & SP & $\begin{array}{l}\text { Mean } \\
\text { Score }\end{array}$ & SD & Rank \\
\hline 1. & During the fishing & $84 \%$ & $16 \%$ & $0 \%$ & $0 \%$ & 1.16 & .368 & $\mathbf{8}$ \\
\hline 2. & During fish selling & $53 \%$ & $35 \%$ & $8 \%$ & $4 \%$ & 1.65 & .833 & 6 \\
\hline 3. & Related with gears and crafts & $74 \%$ & $12 \%$ & $14 \%$ & $0 \%$ & 1.40 & .725 & 7 \\
\hline 4. & In the society & $15 \%$ & $65 \%$ & $13 \%$ & $7 \%$ & 2.12 & .742 & 4 \\
\hline 5. & In the family & $38 \%$ & $42 \%$ & $16 \%$ & $4 \%$ & 1.86 & .829 & 5 \\
\hline 6. & Related to transportation of fish products & $8 \%$ & $26 \%$ & $35 \%$ & $31 \%$ & 2.89 & .942 & 2 \\
\hline 7. & $\begin{array}{l}\text { Obtaining loan from banks and other } \\
\text { financial sources }\end{array}$ & & $5 \%$ & $72 \%$ & $0 \%$ & 3.21 & 1.289 & $\mathbf{1}$ \\
\hline 8. & Owners, labours, buyers and sellers & $5 \%$ & $54 \%$ & $32 \%$ & $9 \%$ & 2.45 & .730 & 3 \\
\hline
\end{tabular}

Sources: Primary Data

From the above table the results reveals that while ranking the problems faced by the fishermen, the mean score (3.21) the highest refers the procurement of finance from banks and other financial sources is a fundamental problem faced by the fishermen because, tedious of formalities. Demanding security for the loans is a hectic problem for the fishermen. Second major problem cited by the respondents is transportation. The respondents expressed that transporting their fish products to market and other places found costly since petrol / Diesel prices, rent for load carriers are more expensive. Problem with owners of boats / launches / crafts, labours, buyers and sellers is the third problem of fishermen. Fixing the wages for labours and rent for crafts, fixation of selling price for fish products are also some of the other problems faced by the fishers.

\section{Findings:-}

The present study highlights some of the major findings are as follows:

$>$ The socio-economic conditions of the fishermen in Puducherry region (villages like Veerampattinam, Vambakeerapalayam and Solainagar) are moderate (neither poor nor good).

$>$ Good majority (92\%) of fishermen belong to Hindu region only 8 per cent belong to Christian community.

$>$ The study reveals that 67 per cent of the fishermen are engaged in active fishing at the age group of more than 40 years. Only 11 per cent of fishermen belong to below 30 years category venture in to sea.

$>$ The study reveals that 88 per cent of the fishermen are married.

$>$ It is found that 65 per cent of the fishermen have primary education only.

$>$ Majority (95\%) of respondents live below the poverty line.

$>$ The study found that 65 per cent of fishermen are living as Nuclear family.

$>$ The study reveals that 63 per cent of fishermen sons venture into sea and involving in fish catch.

$>$ It is also found that 60.2 per cent of fisherwomen engage fish vending. 
$>$ Regarding residence it is found that 63 per cent of fishermen live in Government provided Tsunami houses.

$>$ The study also reveals that 81 per cent of the fishermen live in concrete houses.

$>$ For communication, 86 per cent of fishermen use mobile phone, out of which 70 per cent are smart phone users.

$>$ It is found that all respondents $(100 \%)$ are using electricity for lighting.

$>$ Good majority of the fishermens food habit is rice with fish related dishes.

$>$ The entertainment actives of the fishermen are watching television, newspaper reading and listening FM radio.

$>$ Majority (96 per cent) of respondents opined that there is no conflicts and competition between themselves and inland fishermen.

$>$ The study reveals that 80 per cent of fishermen have toilet facilities. Rest of them use either open space or municipality common toilets for their natural calls.

$>$ The study found that the basic facilities like drinking water, sanitation and healthcare facilities are adequate.

$>$ The study found that the 53 per cent of fishermen monthly income is between Rs. 10,000 and 15,000.

$>$ The study reveals that 76 per cent of fishermen have a habit of consumption of liquor. More than 53 per cent of fishermen spend around 30 per cent of their monthly income for liquor consumption.

$>$ The major problem faced by the fishermen is finance related issues.

\section{Suggestions:-}

The following are the important suggestions.

1. The Government should arrange regular awareness program against use of alcohol, drugs and pan masalas.

2. As per the central Governments clean India programme, the UT administration should ensure the provision of toilets to every house of fishermen so that the use of open space as toilets may be avoided.

3. The children from fisheries communities should be provided with more reservation for their higher education and employment.

4. The government must take steps to solve transportation blocks for the fishing community. So that catched fish can be marketed in the right time at the right place. If there are ways to sell the fish through government channels like fishermen sangam, and through fisheries department etc. will benefit to the fisher folk.

5. Sophisticated markets and processing units should be opened for the marketing of the fish products. Hence it will boost up their economy and paves way to change in the lifestyle.

6. More technical devices should be introduced in the fisheries sector. It will enable the fishermen to catch more fish.

7. Government should make necessary arrangements with bankers for easy availability of bank loans for the financial needs of fishermen community for periodical investments and working capital etc.

\section{Conclusion:-}

Though tremendous increase in GDP from the fisheries sector during the last two decades, living conditions of fishermen all over India is still remains unchanged. In this situation, it is highly essential to take steps to improve their income and reduces their expenditure to obtain a socio-economic balanced society. More particularly, the socio-economic profile of the fishermen in Puducherry region ranked as moderate living, efforts should be taken by the local administration to uplift their lifestyle by providing good education, create awareness and create more responsibility towards the society through various awareness / welfare programmes and financial schemes.

\section{Reference:-}

1. Basavakumar, K. V., Devendrappa, S. and Srenivas, T. (2011) "A study on profile of fishing community of a village in Karnataka" Karanataka Journal Agriculture Science. Vol. 24, Issue. 5, pp. $684-687$.

2. Bijayalakshmi, D.N. and Ajitkumar, N. (2014) "Socioeconomic conditions and cultural profile of the fishers in India- a review" IOSR Journal of Agriculture and Veterinary Science. Vol. 7, Issue. 9, pp. 42-48.

3. Tapashi Gupta and MethraDey (2014) "Socio-economic and cultural profile of fish farmers: A study in and around Lumding town, Nagaon District of Assam" International journal of life science biotechnology and pharma research. Vol. 3, Issue. 4, pp. 83-93.

4. Kadam, M. S. (2015)"Socio economic conditions of fishermen of Masoli Reservoir, in Gangakhed (Tq), Parbhani Dist., Maharashtra state, India" Indian Journal of Applied Research. Vol. 5, Issue. 5, pp. 781-782.

5. Jacob, M.J.K., and Rao, R.B. (2015)"Socio-ecological studies on marine fishing villages in the selective south coastal districts of Andhra Pradesh" Ecotoxicology and Environmental Safety. pp. 1-6. http://dx.doi.org/10.1016/j.ecoenv.2015.08.026i 